\title{
РОКСОЛАНА ПЕТРІВНА ЗОРІВЧАК (на основі особистого листування)
}

\author{
Микола Дупляк \\ Санридж Авеню, 123, м. Камілус, штат Нью-Йорк, США, 13031 \\ mykoladuplak@gmail.com
}

\begin{abstract}
Автор розкриває історію свого спілкування із Роксоланою Зорівчак, яке розпочалося у 1950-х pp. і протривало до останніх днів їі життя. У листах відображено життя українського науковця, яка віддала максимум своїх зусиль на розвиток української науки. Ї̈̈ радощі та труднощі можна перенести на долю кожного національно свідомого науковця. Автор, насильно виселений українець $з$ етнічних українських земель у рамках операції “Вісла”, а згодом емігрант в Америці, є взірцем того, як українці закордоном намагалися працювати для своєї Батьківщини й розвивати ії культуру та науку. Охоплений часовий період показує разючу відмінність між умовами, в яких були українці під час радянського режиму та в час відновленої Української Незалежности. Листи задокументували чимало подій із життя Р. Зорівчак, які стають уже забутими й нерозказаними для майбутніх поколінь.

Ключові слова: Роксолана Зорівчак, історія перекладознавства, українська культура, персонологія.
\end{abstract}

Де б мене не поховали люди, все ж грудка Украйнської землі з мого зажуреного серия буде.

Дмитро Павличко

Я мав приємність і честь листуватися 3 визначною жінкою - педагогом, інтелектуалом, вченою і Патріоткою з великої літери - проф. Роксоланою Петрівною Зорівчак протягом шістдесяти років, отже впродовж усього дорослого життя. Одначе, нагода познайомитись 3 нею особисто трапилася щойно 45 років пізніше - 1994 р., коли вона вперше приїхала до США на конференцію в м. Урбана-Шампейн. Саме тоді трапилась їй перша нагода побачити Америку та відвідати редакцію української газети “Народна воля”, яку я редагував у Скрентоні (штат Пенсильванія). Наша зустріч увінчалась плідною співпрацею на сторінках цього тижневика. До цієї теми повернусь на закінчення статті.

У молодому віці я виростав на польському засланні над Балтійським морем як жертва польської злочинної військової операції “Вісла”. Не можна згадувати цих років добрим словом, але в молодому віці людина легше сприймає наявну невідрадну дійсність, ніж у старшому, зрілому віці. Метою панівного політичного режиму була швидка полонізація українського населення, яке депортували із Закерзоння і розсіяли

(C) Дупляк М., 2020 
на польських понімецьких землях на півночі й заході країни. Я підсвідомо розумів нашу незавидну дійсність, але поляком аж ніяк не хотів стати. Я думав про те, що для збереження нашої національної ідентичности ми повинні виїхати з польського заслання до Радянської України і навіть запропонував цю думку на Першому організаційному з’їзді Українського суспільно-культурного товариства (УСКТ) у Варшаві 1956 р.

У висліді відлиги в суспільно-політичному житті країни та завдяки наполегливим зусиллям генерального секретаря УСКТ Ольги Васильків у навчальному 1957-1958 p. було відкрито секцію української філології як спеціальність навчання і професії у Вчительській студії в Щеціні. Я став студентом україністики рік пізніше. Саме тоді починається моя перша “зустріч” з Роксоланою Петрівною, що переросла в дружбу, яка тривала до останніх днів іiі життя. Нас звела разом українська книжка, а радше іiі відсутність. Справа в тому, що студенти з україністики не мали ніяких українських підручників. У післявоєнній Польщі в першому десятилітті було дуже важко, а то й неможливо придбати будь-яку публікацію українською мовою, а на кожну статтю зі згадкою про Україну та українців ми прямо полювали. На жаль, прихильні та об'єктивні статті майже не зустрічалися. Навпаки, на той час видавнича продукція в Польщі була спрямована проти українців і України, особливо проти українського визвольного руху. Різні публікації змальовували українців як злочинців. У засобах масової інформації панівною була суцільна українофобія. Наші студенти нишпорили по різних антикваріатах, щоб знайти якусь публікацію українською мовою або книжку про Україну будь-якою мовою.

Саме тоді, 1958 р., ми зі студентом Петром Югасом опублікували статтю у варшавському “Нашому слові” про відсутність українських книжок з україністики. Цю газету залюбки читали тоді й у Львові. Статтю прочитала також Роксолана Петрівна. У висліді ми отримали від неї та від кількох інших небайдужих громадян книжкові бандеролі. Книжки надійшли також із Київського університету. Ми раділи, тому що це була перша i, до речі, дуже рідкісна підтримка з Батьківщини, особливо моральна підтримка.

Як і годиться, я подякував Роксолані Петрівні та іншим жертводавцям за надіслану літературу. Ось так і почалося наше листування. Я цікавився культурним й академічним життям в Україні, а вона - життям своїх земляків у Польщі. До речі, книжки з України почали надходити до польських книгарень пізніше. Для нас це була велика радість.

Довголітні контакти з проф. Роксоланою Зорівчак переродилися у справжню дружбу, що проявилася у нашому листуванні. У листі від 14 жовтня 2018 р. вона так про це пише: “... я проводила обчислення Твоїх листів до мене. Вже маю їх - моїх скарбів - 3415. Приблизно стільки ж листів я написала до Тебе. Тільки дуже рідні та близькі люди можуть написати стільки листів!” На жаль, не всі листи Роксолани Петрівни збереглися у мене, хоча їх досить багато. У них п. Роксолана постає для мене представником найкращих вартостей українки та України, особою не лише науки та знання, але й людиною з почуттям національної гідности, яку вона проявляла і захищала всюди, де була така потреба, і де було можна. Я впевнений, що вона була людиною творчої праці Франкового зразка, а таких в Україні не так і багато. Вона - Патріот з великої літери. У листі від 5 грудня 1959 р. між іншим вона пише: “Я завжди дякую 
Богові, що я народилася саме українкою”. Я шанобливо сприймав ії слово. Завдяки iіi листам я був поінформований про те, що діється в Україні в культурному аспекті. Я жив іiї життям, радів іiі успіхам в кожній ділянці та журився іiї турботами, тому що не $з$ легких було життя цієї мудрої та талановитої жінки. Вона жила Україною і для України до останніх днів свого життя, а своїм словом і прикладом заохочувала інших до корисної творчої праці для української науки.

Контактуючи з Україною, я враховував ситуацію і в моїх листах обмежувався прийнятними штампами, що не могли б стати предметом будь-якого оскарження. Вона ж робила те саме. Та все ж таки у Польщі я користувався правом більшої свободи слова, ніж нею користувались в Україні. У нас не було сумніву, що наші листи проходять цензуру. В одному з перших листів 21 січня 1959 р. Роксолана Петрівна пише: “Будьте бадьорі, пам'ятайте старих римлян per aspera ad astra. Жаль мені, що не дозволено Вам навчатись в Україні чи хоча приїхати до нас...” Дійсно, мені не дозволили студіювати в Київському університеті. Коли ж я написав їй про мій намір виїхати до Сполучених Штатів Америки, то в листі від 16 вересня 1959 р. вона написала так: “Сила польського шовінізму мені добре відома. Але як виїде з Польщі наша інтелігенція, то на кого ж залишаться наші діти? Буду вірити, що колись таки зустрінемось (Ї̈і віра здійснилася, але на це треба було довго чекати - М. Д.). У житті я поступала по принципу, вираженому в таких словах: Як радість, всю до дна я п’ю, як горе - хоч убий, не плачу".

До речі, у своєму слові на першому з'ізді УСКТ 1956 р., яке я виголосив польською мовою, я звинуватив владу за те, що не знаю української літературної мови й обіцяв, що всупереч усім перешкодам, я таки повернуся в Україну і нап'юся дніпрової води. Моє бажання здійснилося вже після Чорнобиля.

Проф. Роксолана Зорівчак присилала мені до Польщі, а потім до США, цікаві нові публікації, описувала свої вакації з родиною в Карпатах і в Криму - над Чорним морем, а разом з тим змальовувала красу нашої Батьківщини, в якій мені ніколи не довелося жити. У листі від 19 жовтня 1959 р. просила про самоучок польської мови - для друзів. Я посилав їй польські публікації з українською тематикою.

Завдяки Роксолані Петрівні ми, студенти україністики, привітали Станіслава Людкевича 3 80-річчям. Людкевич, пише вона, - "титан, гігант праці в повному розумінні цього слова, і лише, мабуть, наступні покоління оцінять його по заслугах" (лист від 5 травня 1960 р.).

Під кінець 1960 р., коли я вже емігрував до Америки, Роксолана Петрівна виїхала зі Львова до Москви на курс підвищення кваліфікації. Ми продовжували листуватися. "Найбільше щастя принесли мені дні Декади української літератури та мистецтва в Москві. Тужу за Україною” (лист від 18 березня 1960 р.). Одначе, в Москві Роксолана не отримувала моїх листів з Америки. Опісля натякала в листі на неприємності з владою через мене; нагадувала, щоб я був обережніший.

Згодом у нас почалася активна співпраця. Роксолана Петрівна просила присилати їй різні американські видання, наприклад, “The Golden Geography”, “The Golden Geographic Encyclopedia", "The English Language by Nelson Francis" та чимало інших. Я помагав їй необхідними матеріалами, а вона присилала мені цікаві книжечки. У листі від 2 квітня 1967 р. вона написала: “Стою на роздоріжжі: по історії мови маю дуже доброго та 
зичливого керівника проф. Б. Задорожного. На думку українсько-англійських відносин наштовхує мене проф. Ю. Жлуктенко. Обидві теми потребують Твоєї допомоги”. Не все було під рукою. Довелось розшукувати, але я знаходив бажану річ і посилав, хоч не все доходило до неї, а від неї до мене. Пропадали і листи, і книжки. Така була незавидна радянська режимна дійсність.

Коли ж мати Роксолани Петрівни Лідія Мінко приїхала з онучкою Зоряною до НьюЙорка, я поїхав туди, щоб познайомитися з ними. Про це вона з вдячністю згадує у листі від 18 лютого 1969 р.: “Дуже дякую, що Ти їздив побачитися з Мамою та Зорянкою”.

Роксолана Петрівна міняла теми свого зацікавлення. У листі від 11 березня 1969 р. пише: "Рішила працювати в області англо-українських мовних відносин. Тема: Питання фразеології в перекладах з української мови на англійську. Якщо знайдеш якусь літературу до цієї теми, то пришли, прошу”. I я шукав по бібліотеках, висилав книжки та інформацію про славістів - В. Р. Морфілла, О. Дж. Гантера, Ч. Діккенса, Віру Річ, О. Іваха, Ф. Лайвсей, Е.-Л. Войнич, Гелен Любач, Ф. Т. Марчанта, В. Семенину, Орисю Прокопів та багато інших авторів; про англомовну Шевченкіану і про першого перекладача творів Тараса Шевченка англійською мовою Агапія Гончаренка”. На жаль, не все потрапляло до адресата, та й до адресанта не поверталось.

Чимало з надісланого матеріалу Роксолана Петрівна використала для Шевченківської енциклопедії. Мені ж довелося перевіряти багато неточностей, наприклад щодо Тараса Шевченка та А. Олдріджа, розшукувати бажані теоретичні матеріали, а то й адреси людей. До речі, я замовив фотографічні копії газети “The Alaska Herald”, у яких були Гончаренкові переклади творів Шевченка, але дослідниця порадила не посилати їх, бо побоялась, що пропадуть, подібно як пропали статті про Гончаренка. До речі, вислані статті про Гончаренка, що пропали в дорозі до Львова, я опісля переписував власною рукою, і так вони доходили до адресата, оскільки, видно, цензорам не було легко читати та розшифровувати мій почерк. Така практика вказує і на великі труднощі, що їх треба було долати дослідникові в Україні в радянські часи, і на співпрацю в цьому напрямі 3 однодумцем в Америці. У 1995 р. я мав велику приємність особисто передати "Тhе Alaska Herald" до Шевченкового музею в Каневі. I до мене, і до редакції "Народної волі" у Скрентоні не все доходило. Тут діяла внутрішня цензура. Листи до мене відкривалися i, зовсім можливо, що не все вислане до мене потрапляло.

У листі від 13 грудня 1974 р. Роксолана Петрівна пише: “Енциклопедія ще в процесі опрацювання. Якщо маєш якісь дані, то пришли. А взагалі Ти зробив для цієї публікації дуже багато, як ніхто. Я також зробила, що могла. Як знайдеш, то вишли щось з фразеології або з теоретичних проблем перекладу”. У листі від 18 січня 1977 р. читаємо: "В Шевченківському словнику в першому томі маю 18 статей, не всі підписані. Я з Твоєю допомогою подавала фактаж, а кінцева редакція статей належить редакційній колегіі”.

Сьомого червня 1977 р. в Києві Роксолана Петрівна отримала диплом кандидата філологічних наук, після затвердження ії дисертації Вищою атестаційною комісією в Москві. Тема дисертації була “Фразеологія письменника як проблема перекладу”. Для подальшої дослідницької праці потрібні були матеріали з англомовної Шевченкіани, теорії перекладу та контрастивної лінгвістики (лист від 7 липня 1977 р.). 
Проф. Роксолана Петрівна працювала понад сили. У листі від 16 травня 1979 p. писала: "Відчуваю, що перетворююся в механізм, - нічого крім праці, не знаю. Якби хоча нею могла я користь принести рідному мовознавству! А якщо і користі не буде, $\mathrm{i}$ життя пропаде...” Деколи жалілася мені, що, мовляв, “життя моє щось все важче через те, що мене все більше тягне до бібліотеки, до книжок, відчуваю, що час утікає, що зроблено мало, що не дуже $є$ кому працювати в нашому мовознавстві. Це - на одному полюсі. А на другому -родина, перед якою маю обов’язки" (лист від 2 червня 1979 р.).

Роксолана Петрівна часто їздила до Києва та інших міст України, до Москви, щоб працювати в бібліотеках, брати участь у різних конференціях і нарадах. У Вінниці була головою державної комісії англійського відділення Вінницького університету. Подібні комісії очолювала в інших містах.

У листі від 25 червня 1980 р. вона пише: “Задумала я написати більшу працю на тему українських перекладів творів Дж. Свіфта, Шеллі та Б.Шоу. Вишли видання цих творів, а також усяку критику до них". Бажання Роксолани Петрівни були для мене приємним обов' язком. Я знав, що поміч моїй приятельці, - це поміч українській науці.

У листі від 11 вересня 1980 р. читаємо: “3 1 вересня 1980 р. я на два роки перейшла в докторантуру. У нас такий порядок, що кандидатів наук переводять на два роки на посаду докторантів. Докторанти мають нижчу зарплату, але мають дуже мало лекцій, а повинні весь час працювати над докторськими дисертаціями. Я закріплена для консультацій за відділом романо-германської філології Інституту мовознавства в Києві. Тема моєї роботи - проблеми, що виникають при художніх перекладах в українськоанглійській площині. До докторських робіт у нас ставлять дуже високі вимоги, часто абсолютно непосильні для простих смертних. Мені дуже потрібні такі праці: Zujewskyj Oleh, "The Problems of Ukrainian Artistic Translation" та Loeb Louisa, "The Ukrainian Translations". Напиши щось про “The Saturday Review."

Роксолана Петрівна писала про всі отримані та вислані мені речі, наприклад: “... одержала статтю "Linguistics and Neighboring Disciplines.” Дуже за все дякую, зокрема за писані від руки потебнянські матеріали". Повідомляла також про радісні та сумні події в житті України й часто висловлювала своє ставлення до них. "Перед від'іздом сюди зазнала ще одного горя. Воно, власне, стосується до всіх нас: трагічно загинув композитор Володимир Івасюк, автор "Червоної рути”, "Водограю“"та інших перлин. Я добре знала його, у березні йому минуло 30 років".

Цікаво, що деякі книжки з України не дійшли до мене; їх повернула пошта адресатові, бо “не можна висилати книжок, опублікованих до 1975 року” (лист від 25 грудня 1980 р.).

Роксолана Петрівна писала статті до УРЕ (Української радянської енциклопедії), я ж надсилав їй бажані публікації та матеріали, допоміг наладнати зв 'язок з Вірою Річ та іншими авторами. Корисним, зокрема, виявився “The Ukrainian Quarterly", в якому я знаходив для неї бажані мовознавчі статті.

У листі від 31 липня 1985 р. Роксолана Петрівна пише: “У травні я була два тижні в Києві - працювала в Інституті літератури над розділом монографії "Українськоанглійські літературні зв’язки”. I ще раз усвідомила, скільки для цієї справи зробив Ти. Без Тебе я б собі ніяк ради не дала”. І далі: “Головна редакція УРЕ приступила до 
активної праці над Українською літературною енциклопедією. Усім нам хочеться, щоб вона була авторитетною. І знов просьба до Тебе...”

З листа від 4 квітня 1987 р. довідуємось: “3 1976 р. Атестаційна комісія (у Москві) вимагає, щоб усі документи, включаючи і дисертацію, їй надсилати російською мовою. Більшість - 98\% - у зв'язку з тим пише усе по-російському. Я належу до меншості. Роботи багато: перекладу 390 сторінок машинопису, а передруку і того більше (500 сторінок - туди ще входить список основної використаної літератури і додаток: українсько-англійський словник реалій). Робота ця дуже нудна і просувається черепашиними крочками".

Приємну інформацію приніс лист від 5 травня 1988 р.: “21 січня захистила я у Київському університеті докторську дисертацію. Захист тривав шість годин. Тепер я - “доктор філологічних наук“. Багато працюю тепер для Літературної енциклопедіі”.

У 1994 р. Роксолана Петрівна вперше відвідала США. Приїхала на конференцію до Урбана-Шампейн, яку кожного року влаштовував д-р Дмитро Штогрин, а відтак відвідала редакцію “Народної волі” в Скрентоні, Пенсильванія, де ми вперше познайомились особисто. 3 того часу починається їі плідна співпраця з цим українським американським тижневиком. Авторка надсилала мені цікаві статті, а я ніколи не відмовлявся публікувати їх на сторінках газети. Крім того, я запропонував Роксолані Петрівні вести мовну рубрику в “Народній волі”, і вона погодилася. Я почав друкувати iï 3 листопада 1994 р. Текст рубрики мови я подавав так, як надсилала авторка, тобто чинним в Україні правописом. Всі інші матеріали публікувались у “Народній волі““ за Харківським правописом, чинним у діаспорних виданнях. Матеріали рубрики мови згодом стали основою окремої публікації порад мовознавця під назвою “Боліти болем слова нашого...” (Львів, 2005; Тернопіль, 2008).

Заслуги проф. Роксолани Зорівчак перед Україною та українською наукою дуже великі, а могли б бути ще більші, якщо б у неї були такі умови праці, що дозволяли б і краще жити, і краще піклуватися про своє здоров'я. Та все ж таки вона була щаслива 3 приводу одержання Україною Незалежности та скинення чужого ярма. Дуже відрадним був факт вручення завідувачеві кафедри перекладознавства та контрастивної лінгвістики імені Григорія Кочура, професорові Роксолані Зорівчак державної нагороди - ордену княгині Ольги третього ступеня. Цією високою державною нагородою відзначаються заслуги жінок у розвитку Української держави, духовному відродженні нації, вихованні дітей та молоді. На цю нагороду вона була ідеальним кандидатом і вповні на неї заслужила.

Проф. Роксолана Зорівчак часто нагадувала мені про корисні успіхи, що стали вислідом нашої довголітньої співпраці. Бажаю, однак, нагадати про те, що результатом ii успішної наукової співпраці з Вірою Річ стало розкішне двомовне видання "Мойсея" Івана Франка. Ця публікація, безперечно, підносить авторитет Франкового університету. Я мав приємність написати рецензію на це видання.

Темою нашого листування в останньому році життя проф. Роксолани Зорівчак були здебільшого проблеми іiі здоров’я. У листі з 28 квітня 2018 р. вона написала: “Учора мій робочий день тривав 14 годин, і сьогодні я зовсім безсила“. А потім, у листі від 28 червня, читаємо: “Моє здоров’ я фатально погіршується, але поради собі не маю. Я 
працюю цілими днями, роблю усе, що від мене вимагають, але все важче мені усе це дужати. Консультуюся в лікарів, але їхні поради мені не допомагають”.

У багатьох листах проф. Роксолана Зорівчак висловлювала бажання зустрітися зі мною у Львові. І справді, ми 3 дружиною Галею, донькою Орисею, зятем Йосипом і чотирма внучками побували в Україні в другій половині серпня 2018 р. Саме тоді, менше як два місяці перед смертю, вона гостила нас у своєму помешканні на Підвальній. Це вже була остання з наших кількох зустрічей. Перед тим ми відвідували проф. Роксолану Зорівчак ще за життя ії сина Тараса і чоловіка Василя. Одначе, я не сподівався, що кінець земного життя і турбот моєї Приятельки уже такий близький. В останньому коротенькому комп'ютерному листі від 15 жовтня 2018 р. Роксолана Петрівна писала: “... Кожне слово від Тебе підтримує мене. Я намагаюся лікуватися, але це дуже складно мені. Учора почалася якась сильна задишка, особливо при рухах. Не знаю, що зі мною буде...” Про те, що сталося, я довідався згодом. Нехай же чесне ім'я проф. Роксолани Зорівчак залишиться у великій пошані всіх, хто Її знав, хто з Нею працював, кого Вона навчала й виховувала та всіх, хто в майбутньому читатиме про Її великі заслуги для української науки та виховання молодого покоління свідомих і мудрих українців.

Стаття надійшла до редколегії 10.04.2020

Прийнята до друку 06.05.2020

\title{
ROKSOLANA P. ZORIVCHAK (BASED ON PERSONAL COMMUNICATION)
}

Mykola Duplak

\author{
123, Sunridge Avenue, Camillus, NY, USA, 13031 \\ mykoladuplak@gmail.com
}

The author discloses the history of his communication with Roksolana Zorivchak, which began in the 1950s and lasted until the last days of her life. The letters reflect the life of a Ukrainian researcher who gave her best efforts to develop Ukrainian scholarship. Her joys and difficulties can be transferred to the destiny of every nationally conscious researcher. The author, a forcibly evicted Ukrainian from ethnic Ukrainian lands under the Vistula Action, and later an immigrant to the United States of America, is an example of how Ukrainians abroad sought to work for their homeland and develop its culture and scholarship. Living far away from the Fatherland, the author experienced all the hardships of an immigrant's life and wanted his countrymen to live in a free and independent Ukraine so that they could live a better life and fulfill their cultural, economic and political needs as all free people in the world do. For this to happen, he was working and dreaming all his life. The time period covered shows the striking difference between the conditions that Ukrainians had to work under during the Soviet regime and during the restored Ukrainian Independence. The letters have documented a lot of events in the life of R. Zorivchak, which are already getting forgotten and untold for future generations.

Key words: Roksolana Zorivchak, history of translation studies, Ukrainian culture, personology, 